\title{
Biomarkers of oogenesis in Macoma balthica determined by subtractive immunization
}

\author{
Erin Bromage ${ }^{1,3}$, W. Christopher Long ${ }^{2,4}$, Stephen Kaattari ${ }^{1, *}$ \\ ${ }^{1}$ Department of Environmental and Aquatic Animal Health, and ${ }^{2}$ Department of Biological Sciences, School of Marine Science, \\ Virginia Institute of Marine Science, College of William and Mary, Gloucester Point, Virginia 23062, USA \\ ${ }^{3}$ Department of Biology, University of Massachusetts Dartmouth, 285 Old Westport Rd., North Dartmouth, \\ Massachusetts 02747, USA \\ ${ }^{4}$ Present address: Smithsonian Environmental Research Center, 647 Contees Wharf Road, PO Box 28, Edgewater, \\ Maryland 21037, USA
}

\begin{abstract}
We employed the technique of subtractive immunization (SI) to identify specific biomarkers of oocyte development in Macoma balthica. Analysis revealed that 2 novel proteins (45 and $96 \mathrm{kDa})$ were induced during female gametogenesis that were neither present during other life stages, nor in male clam tissues. A total of 78 viable hybridomas were specific for either the 45 or $96 \mathrm{kD}$ M. balthica proteins. Subsequent peptide fragment analysis of the $96 \mathrm{kDa}$ protein revealed that it was essentially identical (>99.9\%) to the evolutionarily conserved heat shock protein 70 family. The resultant hybridomas were screened for their utility in a quantitative capture ELISA configuration. Two antibody systems were designed that allowed the quantification of either the 45 or $96 \mathrm{kDa}$ protein in $M$. balthica tissue homogenates and are useful for studies on $M$. balthica gametogenesis and fecundity. Subtractive immunization is a powerful tool, as it simultaneously identifies novel protein targets while producing monoclonal antibodies specific to them.
\end{abstract}

KEY WORDS: Subtractive immunology · Macoma balthica $\cdot$ Gametogenesis $\cdot$ ELISA $\cdot$ Monoclonal antibodies · Oocyte

Resale or republication not permitted without written consent of the publisher

\section{INTRODUCTION}

The motivation for the present study originated from a larger research project examining the effects of hypoxia, or low concentrations of dissolved oxygen, on the tellenid clam Macoma balthica in Chesapeake Bay (Long 2007). M. balthica is native to estuarine systems in both North America and Europe and is important both ecologically and economically. In Europe, it is an important source of food for migrating shorebirds (Stillman et al. 2005), and in Chesapeake Bay it dominates the biomass in mesohaline muddy habitats (Holland et al. 1977) and comprises $>50 \%$ of the diet of the important fishery species Callinectes sapidus, the blue crab (Hines et al. 1990). M. balthica is well studied on both sides of the Atlantic and is considered a marker of a healthy ecosystem, as it is moderately sensitive to environmental stressors such as hypoxia (Powers et al. 2006). We hypothesized that one of the effects of sublethal exposure to hypoxia would be decreased oocyte production, similar to the effects in other species (e.g. Condon et al. 2001, Wu \& Or 2005). Although aspects of the reproductive cycle in $M$. balthica have been investigated, primarily in the eastern Atlantic, the studies have relied on either qualitative ranking of gonad fullness (e.g. De Goeij \& Honkoop 2003) or the use of microscopy to manually count oocytes (Honkoop et al. 1999, Beukema et al. 2001) in order to estimate oocyte production. As the former method was not quantitative enough for our purposes, and the latter was too labor intensive, we decided to use an enzymelinked immunosorbent assay (ELISA) to quantify oocyte production in $M$. balthica, as has been done in other bivalve species (e.g. Park \& Choi 2004). 
In order to develop the ELISA, we first required monoclonal antibodies (MAbs) to protein targets uniquely expressed in Macoma balthica oocytes. Our early studies focused on identifying protein markers that were indicative of egg development in M. balthica. Proteomic comparison of mature versus immature female homogenates did not reveal promising target proteins. Therefore, we pursued the use of subtractive immunization (SI) to identify suitable biomarkers (Long et al. 2008, in this issue). This method now permits greatly facilitated, quantitative assessments of clam fecundity, while also providing probes that can be used to isolate and characterize critical clam proteins involved in egg production.

\section{MATERIALS AND METHODS}

Preparation of tissue extracts. Juvenile and adult Macoma balthica were collected from the York River, Virginia, USA, and stored at $-20^{\circ} \mathrm{C}$ until analysis. The clam shells were opened, and small samples of the gonad from each animal were collected and examined under the microscope to identify those containing oocytes. Oocytes from mature females were collected, pooled and homogenized in phosphate-buffered saline (PBS; $100 \mathrm{mM}$ phosphate, $150 \mathrm{mM} \mathrm{NaCl}, \mathrm{pH}$ 7.4). The resulting suspension was centrifuged at $12000 \times g$ for $30 \mathrm{~min}$ and stored at $-80^{\circ} \mathrm{C}$ until required. Male clams, non-reproductively viable juvenile clams, and siphon tissue were also collected and processed in the same way. Total protein concentration for each sample was measured using a bicinchoninic acid assay (Sigma).

Immunization protocol. Six week old female BALB/CJ mice from the VIMS breeding colony were used in all experiments and cared for under National Research Council (NRC) guidelines for the care and use of laboratory animals. Three mice were immunized via intraperitoneal (IP) injection with $50 \mu \mathrm{g}$ of juvenile clam extract (tolerogen) at a 1:1 emulsion with Freund's incomplete adjuvant (FIA). At 1, 3 and $7 \mathrm{~d}$ following immunization, mice were administered cyclophosphamide (cy; Sigma) IP at a dose of $100 \mathrm{mg} \mathrm{kg}^{-1}(\sim 2 \mathrm{mg}$ mouse $\left.^{-1}\right)$. On Day 10, the mice were IP injected with $50 \mu \mathrm{g}$ of oocyte protein extract (immunogen) emulsified at a 1:1 ratio with FIA, with a second boost of $10 \mu \mathrm{g}$ oocyte protein 3 d later. At 60, 90 and 120 d after the initial immunization, serum from each mouse was collected and titered for an immune response against oocyte, juvenile clam, and siphon protein using an ELISA (described in 'Materials and methods-ELISA'). The best responder, at $120 \mathrm{~d}$, to oocyte protein was boosted intravenously with $5 \mu \mathrm{g}$ oocyte protein, and the fusion was conducted 4 d later.
Hybridoma production. One week prior to the fusion, the myeloma cell line SP 2/0 Ag 14 was grown in Commonwealth Serum Laboratories-Dulbecco modified Eagle's medium (CSL-DMEM) supplemented with $20 \%$ fetal calf serum (Hyclone) and $1 \%$ of oxalacetate, pyruvate, and insulin supplement (OPI; Sigma). Splenocytes were harvested from the immunized mouse, and red blood cells were lyzed using cell lysis buffer (Sigma). The splenocytes and SP 2/0 were mixed at a ratio of 1:5; the cells were fused using hybrimax polyethylene glycol (Sigma), and the reaction was terminated by the addition of $10 \mathrm{ml}$ of CSL-DMEM over a period of $20 \mathrm{~min}$. Fused cells were resuspended in CSL-DMEM supplemented with $20 \%$ fetal calf serum, $1 \%$ OPI, and $1 \%$ hypoxanthine-aminopterinthymidine (HAT; Sigma), and aliquoted into 96-well tissue culture plates (Costar). Ten days following the fusion, cell culture supernatants were screened against both oocyte and juvenile clam proteins, and positive hybridomas were expanded and cloned. All MAbs from cloned hybridomas were sub-isotyped using the Sigma isotyping kit, following the manufacturer's protocol (Sigma).

ELISA. Assessments of mouse sera titers and tissue culture supernatants were performed using an indirect ELISA. The 96-well microplates (Costar, high binding) were coated with $1 \mu \mathrm{g} \mathrm{ml}^{-1}$ of either immunogen, tolergen, or negative controls prepared in carbonate coating buffer $\left(\mathrm{CCB} ; 15 \mathrm{mM} \mathrm{Na} \mathrm{CO}_{3}, 17.4 \mathrm{mM} \mathrm{NaHCO}\right.$, $\mathrm{pH}$ 9.6). The coated plates were allowed to incubate for $1 \mathrm{~h}$ at room temperature. The residual protein-binding sites on the ELISA plates were blocked with $1 \%$ bovine serum albumin (BSA) in Tris-buffered saline with $0.1 \%$ Tween 20 (TTBS; $50 \mathrm{mM}$ Tris, $150 \mathrm{mM}$ $\mathrm{NaCl}, 1 \mathrm{mM}$ EDTA, $0.1 \%$ Tween 20, pH 7.5). Immune sera or cell culture supernatants were serially diluted in TTBS, and $100 \mu \mathrm{l}$ was added to the plate in duplicate and incubated for $1 \mathrm{~h}$ at room temperature. Detection was performed with goat-anti-mouse Fc-specific antibody conjugated with horseradish peroxidase (HRPO) (1:4000, Jackson ImmunoLabs) and quantified with 2,2'-azino-bis(3-ethylbenzthiazoline-6-sulphonic acid) (ABTS) development.

To quantify the levels of oocyte proteins in clam homogenates, a capture ELISA was developed using appropriately selected MAbs. All hybridomas resulting from the fusion were initially assessed for titer (as described above) and specificity (Western blot, described below). Those hybridomas displaying both high titer and Western blot specificity were Protein A purified (BioRad), and a portion of the purified antibody was biotinylated with N-hydroxysuccimide (NHS)-biotin using a labeling kit (Pierce). ELISA plates were coated with $5 \mu \mathrm{g} \mathrm{ml}^{-1}$ of the unlabeled capture antibody as described above. Of the test extracts, $50 \mu \mathrm{g}$ was added to all wells and incubated 
for $1 \mathrm{~h}$, followed by the addition of $2 \mu \mathrm{g} \mathrm{ml}^{-1}$ of the biotinylated detection antibodies. Detection of the complex was performed with streptavidin HRPO (1:4000) and ABTS. The rate of reaction was measured, and the wells showing a significant increase in the rate of reaction compared to the standard (containing known oocyte protein concentrations) and controls (no oocyte protein present) were analyzed further.

Western blotting and protein identification. The specificity of MAbs was further characterized via Western blotting. Oocyte and juvenile protein extracts were electrophoresed under reducing and non-reducing conditions on $10 \%$ sodium dodecyl sulfate polyacrylamide gel electrophoresis (SDS-PAGE) gels (Harlow \& Lane 1999), and transferred to polyvinylidene fluoride (PVDF) (Immobilon-P; Millipore) following the manufacturer's instructions. The membrane was blocked with blocking solution (Licor) and probed with the monoclonal antibodies. Detection was performed with goat-anti-mouse IR680 (1:5000, Licor) and visualized with the LiCor Odyssey detection system.

For protein identification, $1 \mathrm{ml}$ of activated $\mathrm{CNBr}$ activated sepharose beads (GE Healthcare Life Sciences) were coated with $5 \mathrm{mg}$ of antibody (7A4) following the manufacturer's protocol. Then, $2 \mathrm{ml}$ of the oocyte protein extract containing $16.5 \mathrm{mg}$ of total protein was mixed with $8 \mathrm{ml}$ of PBS and added to the antibody-coated beads. The solution was incubated at $4^{\circ} \mathrm{C}$ overnight, with gentle agitation. Following incubation, the beads were allowed to settle and the supernatant was removed and discarded. The beads were subsequently washed 10 times with $10 \mathrm{ml}$ of PBS. The antibody-bound protein was eluted using 0.5 M glycine ( $\mathrm{pH} 3.0)$, and immediately dialyzed against PBS. The purity of the eluted protein was confirmed via SDS-PAGE; and amino acid sequencing via LCMS/MS of the purified protein was performed by Protech Inc. Peptide fragments were compared to known sequences (NCBI BLASTP).

\section{RESULTS}

\section{Response to Macoma balthica antigens}

Following SI, mouse titers were assessed for reactivity to $M$. balthica oocyte, juvenile, and siphon protein extracts. None of the sera from the tolerized mice displayed reactivity to either juvenile clam or siphon tissue extracts at 60,90, or $120 \mathrm{~d}$ following immunization. In contrast, all mice displayed a specific response for oocyte proteins, with Mouse 'AB' displaying the greatest titer and minimal reactivity with the other protein extracts. Non-tolerized mice demonstrated a significant titer to all the clam tissues (Fig. 1).

\section{Hybridoma production}

Following the fusion, all wells were tested for specific antibodies to both the immunogen and tolerogen. Seventy-eight wells (out of 960) possessed oocytespecific antibodies in their supernatant, as defined by an OD 10 times greater than the background OD. None of the wells possessed antibodies specific to juvenile clam proteins.

\section{Specificity of MAbs}

Ten of the MAbs were chosen for further evaluation following cloning. All MAbs were of the immunoglobin $\mathrm{IgG}_{1}$ isotype, except for 9G5 and 10F11, which were $\mathrm{IgG}_{2 \mathrm{~b}}$. Under non-reducing denaturing conditions, the Western blotting profiles indicated that all 10 MAbs were specific to either a 45 or $96 \mathrm{kDa}$ protein (Fig. 2). The antibodies also recognized denatured and reduced 42 and $74 \mathrm{kDa}$ forms (data not shown). None of the MAbs showed reactivity when screened against juvenile clam protein or siphon protein (Fig. 2).
Fig. 1. Specificity of (A) nontolerized and (B) tolerized mouse sera following immunization with mixed protein extracts. The nontolerized mouse was immunized with clam Macoma balthica oocyte protein extracts, and the tolerized mouse was immunized with juvenile clam protein followed by cyclophosphamide treatment, then subsequently immunized with clam oocyte protein extracts. The mice were assessed for titer against 3 clam tissue homogenates $120 \mathrm{~d}$ after initial injection
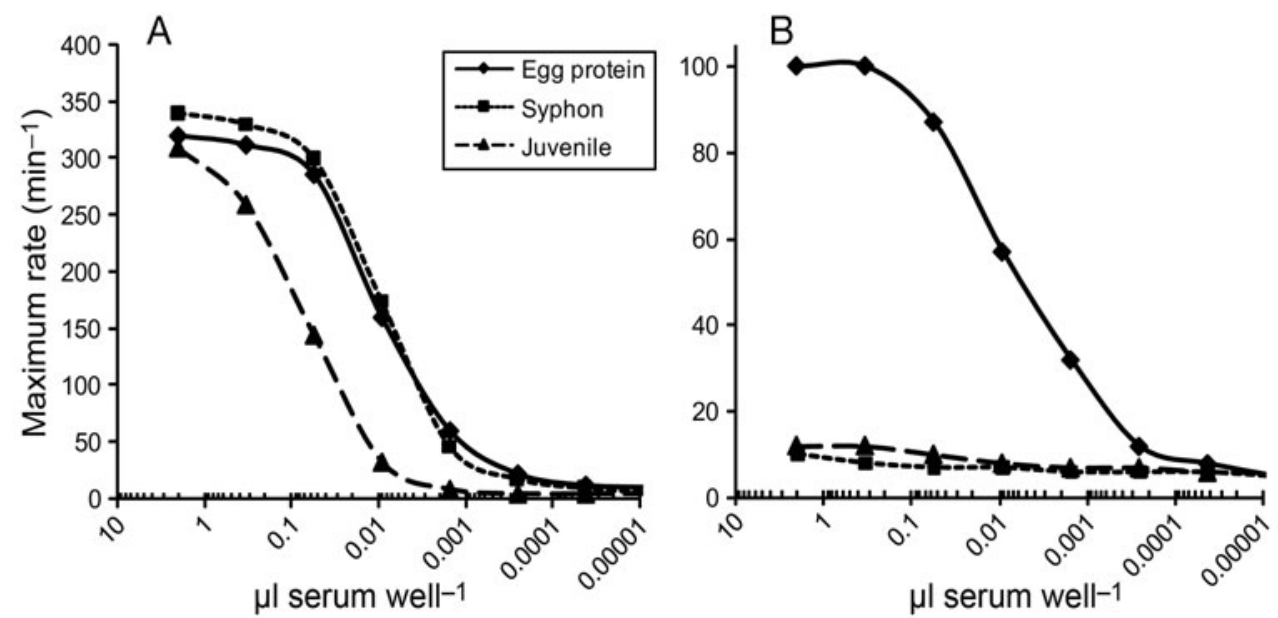

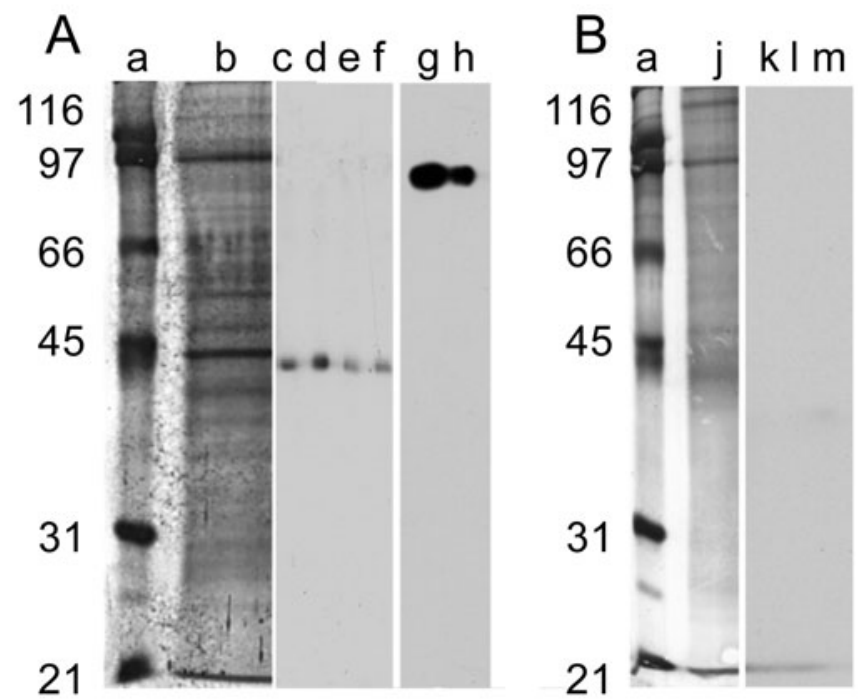

Fig. 2. Western blotting profile of a representation selection of monoclonal antibodies generated following subtractive immunization. (A) Monoclonal antibodies were screened for their specificity to Macoma balthica oocyte proteins under non-reducing conditions. a: molecular weight markers; $\mathrm{b}$ : total protein stain of a protein homogenate from a mature female clam; c: 9G5; d: 10F11; e: 4G6; f: 10C3; g: 3B8; h: 7A4. (B) The antibodies were not reactive when screened against juvenile clam homogenates. a: molecular weight markers; $\mathrm{j}$ : total protein stain of juvenile clam homogenates; $\mathrm{k}$ : 3B8;

$$
\text { 1: 7A4; m: 9G5 }
$$

\section{Development of quantitative ELISA}

The ELISA screening system identified MAbs that would allow the capture and detection of the oocyte proteins in mixed protein samples. When the plate was coated with $96 \mathrm{kDa}$, protein-specific 3B8 or 7A4, either biotinylated 3B8 or biotinylated 7A4 was able to detect bound protein (Fig. 3). Of the remaining MAbs, only 9G5 and 10F11 proved effective for capture of oocyte proteins and could be detected with biotinylated 3D2, $4 \mathrm{G} 6,6 \mathrm{~B} 2,9 \mathrm{H} 1,9 \mathrm{H} 5$, or $10 \mathrm{C} 3$.
Utilizing these results, an optimized capture ELISA was developed using 7A4 and biotinylated 7A4 to quantify the $96 \mathrm{kDa}$ protein in either homogenates of eggs recovered from mature female clams or from whole homogenates of mature female clams. Plates were coated with $7 \mathrm{~A} 4$ (5 $\mathrm{g} \mathrm{ml}^{-1}$ in CCB), and captured oocyte-specific proteins were detected with biotinylated 7A4 $\left(2 \mu \mathrm{g} \mathrm{ml}^{-1}\right)$, followed by streptavidin HRPO and ABTS detection. This ELISA system did not crossreact when tested using juvenile, siphon, or male clam protein extracts (Fig. 4).

\section{Protein identity}

From the $2 \mathrm{ml}$ (16.5 $\mathrm{mg}$ ) of egg extract used in the purification, $120 \mu \mathrm{g}$ of protein were recovered (<1\% of the total protein). Nine peptide fragments were recovered, identified from the LC-MS/MS sequencing, and compared to known proteins (Table 1). All peptide fragments were homologous to the evolutionarily conserved heat shock protein 70 family (HSP70).

\section{DISCUSSION}

Oocyte-specific proteins of Macoma balthica were efficiently targeted for MAb production by SI, even though they were in very low $(<1 \%)$ abundance. These MAbs have been successfully used to develop a quantitative ELISA that determines the number of oocytes in a mature $M$. balthica (Long et al. 2008). This ELISA has subsequently been used to determine the effect of hypoxic stress on $M$. balthica oocyte production (Long 2007). Although similar assays have been developed for use in other bivalve species (e.g. Park \& Choi 2004), these relied on polyclonal antibodies, partially because of the difficulty in selecting targets: the whole-protein profile of $M$. balthica oocyte homogenate, for example,
$96 \mathrm{kDa}$ protein

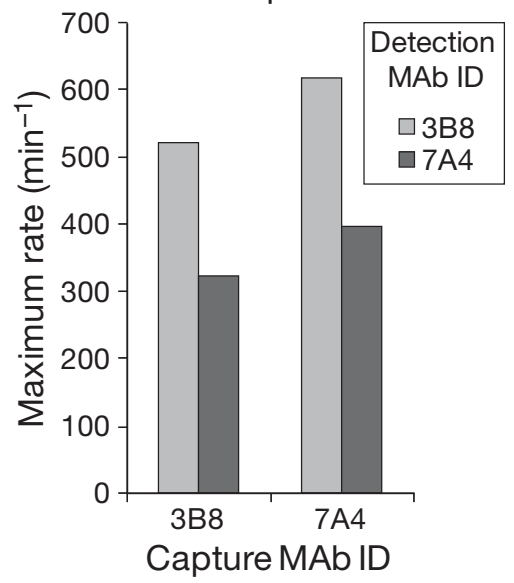

\section{$45 \mathrm{kDa}$ protein}

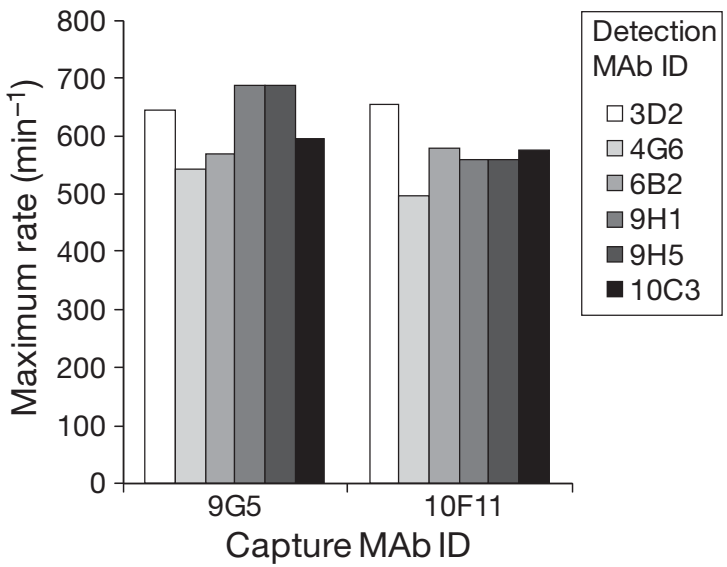

Fig. 3. Capture ELISAs developed for the quantification of biomarker proteins in Macoma balthica. Capture monoclonal antibodies (MAbs) were utilized with biotinylated detection antibodies to detect their respective proteins, followed by the addition of $10 \mu \mathrm{g}$ of oocyte homogenates 


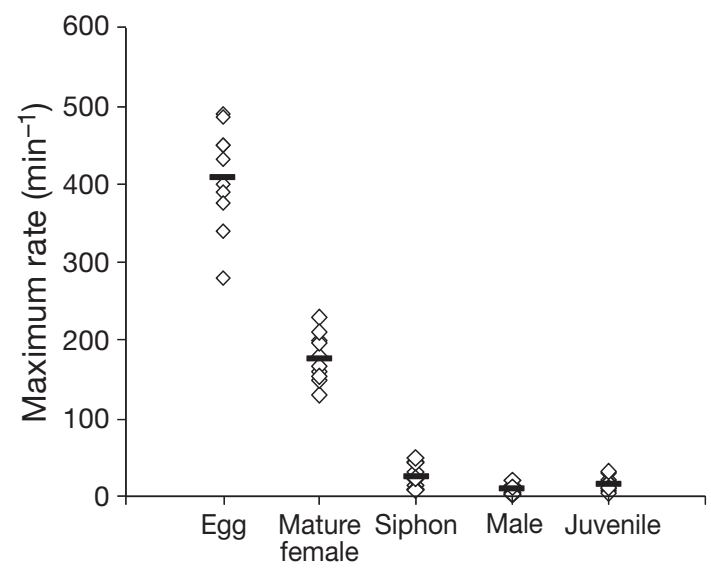

Fig. 4. Specificity of capture ELISAs for the detection of Macoma balthica oocyte-specific proteins. The ELISAs developed (7A4, biotinylated 7A4) for the quantification of the $96 \mathrm{kDa}$ oocyte proteins show minimal cross-reactivity with proteins present in whole-protein extracts from siphon tissue, juvenile clams, or male clams, while demonstrating specificity for protein found in eggs excised from mature females or from whole-tissue homogenates (including eggs) of mature females

consists of $>200$ proteins. Although a comparison of 1-dimensional protein profiles between oocyte and juvenile homogenates suggested that several novel proteins were present in the oocytes, the purification of sufficient quantities of these proteins for use in MAb production would have been difficult and there would have been no guarantee that they would make suitable targets. Indeed, neither of the proteins selected by SI had been identified as potential targets by 1 -dimensional analysis, indicating that either those targets were not unique, but merely up-regulated, or that they were poorly immunogenic. In either case, they would have been poor choices for our purposes.

Immunizing mice with juvenile clam homogenates and immediately treating them with cyclophosphamide tolerized them to these common antigens. Thus, upon immunization with the oocyte homogenate, the murine immune system only recognized those proteins that were unique to female gametogenesis. The absence of a serum titer to juvenile or siphon tissue $120 \mathrm{~d}$ after initial tolerization demonstrated the efficacy of this technique (Fig. 1). Further, the effectiveness of cyclophosphamide tolerization was demonstrated by the complete absence of viable hybridomas to juvenile clam extracts ( $0 / 78$ colonies) following the fusion. The length of tolerance is atypical of SI protocols, where fusion of the spleen cells is usually performed 1 to 2 mo following immunization (Yang \& Wang 2002, Hooper et al. 2003). The breaking of tolerance is due to the short half-life of cyclophosphamide, which is typically $<10 \mathrm{~h}$ (Mouridsen et al. 1976), leading to the reestablishment of the mouse's normal immune cell repertoire. However, as tolerance was not broken, evidenced by the lack of titer to tolerogen at Day 120, it is obvious that it takes considerable time to re-establish a normal B-cell repertoire and function (Zandvoort et al. 2001).

The 10 hybridomas selected for cloning and evaluation were specific for either a 45 or $96 \mathrm{kDa}$ protein via Western blot, and were absent in juvenile and siphon tissues. Only the $96 \mathrm{kDa}$ protein was readily visible on Commassie blue-stained gels and was able to be recovered in a sufficient quantity via immuno-adsorption to allow the protein to be sequenced. The various peptide fragments from the $96 \mathrm{kDa}$ protein were homologous to peptide sequences from the HSP 70 family of proteins (Table 1). Due to the absence of this protein in juvenile, male, and female clams without oocytes, we suggest that this is an inducible HSP that is expressed during oocyte development. Heat shock proteins, or molecular chaperone proteins, are expressed during gametogenesis in a number of species (Angelier et al. 1996, Marin \& Tanguay 1996, Knoll-Gellida et al. 2006). The role of HSPs during gametogenesis has not been resolved, but they may be involved in transfer of maternal proteins to the developing oocyte. Thus, they make excellent targets for identifying oocyte development in females.

For our purposes, it was necessary to quantify the target protein concentration. Western blotting is the

Table 1. Macoma balthica. Identity of the peptide sequences obtained from LC-MS/MS amino acid sequencing of purified $96 \mathrm{kDa}$ protein induced during oocyte development

\begin{tabular}{|llcc|}
\hline Peptide sequence & BLASTP identity (closest match) & Identities & $E$ value \\
\hline TVTNAVVTVPAYFNDSQR & HSP 70 [Culex pipiens quinquefasciatus] & $18 / 18$ & $17 / 17$ \\
IINEPTAAAIAYGLDKK & HSP 70 [Moina macrocopa] & $16 / 16$ & $2^{-8}$ \\
IINEPTAAAIAYGLDK & HSP 1-like protein [Mus musculus] & $16 / 16$ & $3^{-7}$ \\
STAGDTHLGGEDFDNR & HSP 70 [Moina macrocopa] & $13 / 13$ & $3^{-6}$ \\
TTPSYVAFTDTER & HSP 1-like protein [Mus musculus] & $14 / 14$ & $3^{-6}$ \\
SQIHDIVLVGGSTR & HSP 70 cytosolic [Andalucia godoyi] & $12 / 12$ & $7^{-4}$ \\
DAGTIAGLNVLR & HSP 70 [Culex pipiens quinquefasciatus] & $11 / 11$ & 0.045 \\
VEIIANDQGNR & HSP 1-like protein [Mus musculus] & $10 / 10$ & 0.06 \\
FEELNADLFR & HSP 70 [Fasciola hepatica] & & 0.26 \\
\hline
\end{tabular}


typical method used for the detection and quantification of HSP production in invertebrates (Werner 2004, Villeneuve et al. 2006), but it is laborious when numerous samples need to be analyzed. An alternate strategy is the employment of a quantitative ELISA (Harlow \& Lane 1988). The optimum ELISA configuration for the quantification of a target protein is through the use of a capture-detect system. This ELISA configuration involves an antibody coated onto the ELISA plate to capture the target protein that is subsequently detected with a labeled antibody that is also specific to the target protein. This ELISA design is often not possible, as either the target must have repeating epitopes that can be recognized by a single antibody, or one must employ 2 antibodies that recognize mutually exclusive epitopes. Using a checkerboard ELISA configuration, we were able to identify antibody pairings that worked in a capture-detect ELISA. The MAbs 3B8 and $7 \mathrm{~A} 4$, which are specific for the $96 \mathrm{kDa}$ oocyte protein, demonstrated combined recognition when paired (capture/detected: 3B8/biotinylated 3B8, 3B8/biotinylated 7A4，7A4/biotinylated 7A4，7A4/biotinylated 3B8; Fig. 3). This suggested that the 96kDa oocyte protein possessed repeated epitopes, and that a single antibody can be utilized for a quantitative ELISA. The remaining antibodies were all directed to the $45 \mathrm{kDa}$ protein (Fig. 2), and the optimum configuration used either 9G5 or 10F11 as capture antibodies, coupled with biotinylated 3D2, 4G6, 6B2, 9H1, 9H5, or 10C3 for detection (Fig. 3). Other antibody pairings were not obvious choices for ELISA development. Thus, 2 ELISA systems were optimized for the quantification of either the 45 and $96 \mathrm{kDa}$ proteins. Often researchers utilize an inferior ELISA design (Cimino et al. 2002, Boutet et al. 2004) for antigen quantification, where they coat the solution containing the target protein directly onto the plate. They subsequently use their primary antibody to detect the relative amount of their target bound onto the plate. However, this type of ELISA (indirect) is fraught with potential errors due to the competition for available binding sites with other proteins present in the coating solution (Kenny \& Dunsmoor 1983). This leads to an underestimation of the target in the test sample, especially when the target antigen's concentration is $<1 \%$ of the total protein loaded onto the plate (Kenny \& Dunsmoor 1983).

The use of SI is a strong but under-utilized means of identifying unique antigens in complex clam protein mixtures. We utilized this technique to identify proteins and generate MAbs against protein biomarkers indicative of gametogenesis in Macoma balthica, including one that was not visible in SDS-PAGE analysis. This was achieved without the requirement to identify or purify the antigen prior to immunization. This has a multitude of potential applications in many areas of biological inquiry. For example, it could be used to identify proteins induced by stressors such as temperature, pollution, hypoxia, $\mathrm{pH}$, injury, or infection (Christie et al. 1994), or proteins induced by processes such as development, gametogenesis, or hibernation. Molecular biologists can then investigate the roles of these marker proteins, or ecologists can identify individuals exposed to stressors.

Acknowledgements. W.C.L. was supported by an EPA GRO fellowship. This project was also supported by the Commonwealth of Virginia and a grant from the Graduate Student Association of the Virginia Institute of Marine Science. We thank J. C. A. Long and 2 anonymous reviewers whose comments substantially improved earlier versions of this manuscript. This is Contribution 2936 from the Virginia Institute of Marine Science.

\section{LITERATURE CITED}

Angelier N, Moreau N, Rodriguez-Martin ML, PenradMobayed M, Prudhomme C (1996) Does the chaperone heat shock protein hsp70 play a role in the control of developmental processes? Int J Dev Biol 40:521-529

Beukema JJ, Drent J, Honkoop PJC (2001) Maximizing lifetime egg production in a Wadden Sea population of the tellenid bivalve Macoma balthica: a trade-off between immediate and future reproductive outputs. Mar Ecol Prog Ser 209:119-120

Boutet I, Tanguy A, Moraga D (2004) Response of the Pacific oyster Crassostrea gigas to hydrocarbon contamination under experimental conditions. Gene 329:147-157

Christie KE, Hjeltnes B, Totland GK, Flood PR, Spasowska B (1994) Infective salmon anaemia (ISA)-associated monoclonal antibodies generated by subtractive immunization. In: International symposium on aquatic animal health: program and abstracts. University of California, School of Veterinary Medicine, Davis, CA

Cimino EJ, Owens L, Bromage E, Anderson TA (2002) A newly developed ELISA showing the effect of environmental stress on levels of hsp86 in Cherax quadricarinatus and Penaeus monodon. Comp Biochem Physiol 132: 591-598

Condon RH, Decker MB, Purcell JE (2001) Effects of low dissolved oxygen on survival and asexual reproduction of scyphozoan polyps (Chrysaora quinquecerrha). Hydrobiologia 451:89-95

De Goeij P, Honkoop PJC (2003) Experimental effects of immersion time and water temperature on body condition, burying depth and timing of spawning of the tellenid bivalve Macoma balthica. Helgol Mar Res 57:20-26

Harlow E, Lane D (1988) Immunoassays. Antibodies: a laboratory manual. Cold Springs Harbor Laboratory Press, Cold Springs Harbor, NY, p 553-612

Harlow E, Lane D (1999) Appendix 1: electrophoresis. Using antibodies. A laboratory manual. Cold Springs Harbor Laboratory Press, Cold Springs Harbor, NY, p 409-434

Hines AH, Haddon AM, Wiechert LA (1990) Guild structure and foraging impact of blue crabs and epibenthic fish in a sub-estuary of Chesapeake Bay. Mar Ecol Prog Ser 67: 105-126

Holland AF, Mountford NK, Mihursky J (1977) Temporal variation in upper bay and mesohaline communities. I. The 9-m mud habitat. Chesap Sci 18:370-378 
Honkoop PJC, van der Meer J, Beukema JJ, Kwast D (1999) Reproductive investment in the intertidal bivalve Macoma balthica. J Sea Res 41:203-212

Hooper JD, Zijlstra A, Aimes RT, Liang H and others (2003) Subtractive immunization using highly metastatic human tumor cells identifies SIMA135/CDCP1, a $135 \mathrm{kDa}$ cell surface phosphorylated glycoprotein antigen. Oncogene 22:1783-1794

Kenny GE, Dunsmoor CL (1983) Principles, problems, and strategies in the use of antigenic mixtures for the enzymelinked immunosorbent assay. J Clin Microbiol 17:655-665

Knoll-Gellida A, Andre M, Gattegno T, Forgue J, Admon A, Babin PJ (2006) Molecular phenotype of zebrafish ovarian follicle by serial analysis of gene expression and proteomic profiling, and comparison with the transcriptomes of other animals. BMC Genomics 7:46

Long WC (2007) Hypoxia and Macoma balthica: ecological effects on a key benthic infaunal species. $\mathrm{PhD}$ dissertation, College of William and Mary, Virginia Institute of Marine Science, Gloucester Point, VA. Available at: www.vims.edu/ library/Theses/Long07.pdf

Long WC, Bromage E, Seitz RD, Kaattari S (2008) Quantifying fecundity in Macoma balthica using an enzyme-linked immunosorbent assay (ELISA). Aquat Biol 3:187-193

> Marin R, Tanguay RM (1996) Stage-specific localization of the small heat shock protein Hsp27 during oogenesis in Drosophila melanogaster. Chromosoma 105:142-149

Mouridsen HT, Faber O, Skovsted L (1976) The metabolism of cyclophosphamide. Dose dependency and the effect of long-term treatment with cyclophosphamide. Cancer $37: 665-670$

Editorial responsibility: Roderick Finn,

Bergen, Norway
Park KI, Choi KS (2004) Application of enzyme-linked immunosorbent assay for studying of reproduction in the Manila clam Ruditapes philippinarum (Mollusca: Bivalvia). I. Quantifying eggs. Aquaculture 241:667-687

Powers SP, Peterson CH, Christian RR, Sullivan E, Powers MJ, Bishop MJ, Buzzelli CP (2005) Effects of eutrophication on bottom habitat and prey resources of demersal fishes. Mar Ecol Prog Ser 302:233-243

Stillman RA, West AD, Goss-Custard JD, McGrorty S and others (2005) Predicting site quality for shorebird communities: a case study on the Humber estuary, UK. Mar Ecol Prog Ser 305:203-217

Villeneuve TS, Ma X, Sun Y, Oulton MM, Oliver AE, MacRae TH (2006) Inhibition of apoptosis by p26: implications for small heat shock protein function during Artemia development. Cell Stress Chaperones 11:71-80

Werner I (2004) The influence of salinity on the heat-shock protein response of Potamocorbula amurensis (Bivalvia). Mar Environ Res 58:803-807

> Wu RSS, Or YY (2005) Bioenergetics, growth and reproduction of amphipods are affected by moderately low oxygen regimes. Mar Ecol Prog Ser 297:215-223

Yang LJ, Wang WL (2002) Preparation of monoclonal antibody against apoptosis-associated antigens of hepatoma cells by subtractive immunization. World J Gastroenterol 8:808-814

> Zandvoort A, Lodewijk ME, Klok PA, Dammers PM, Kroese FG, Timens W (2001) Slow recovery of follicular B cells and marginal zone B cells after chemotherapy: implications for humoral immunity. Clin Exp Immunol 124: $172-179$

Submitted: October 26, 2007; Accepted: June 20, 2008 Proofs received from author(s): July 25, 2008 